\title{
Known Range Expansion and Morphological Variation in the Southern Flying Squirrel (Glaucomys volans) in Quebec
}

\author{
Louis Lazure ${ }^{1,6}$, Patrick Paré ${ }^{1}$, Nathalie Tessier ${ }^{2,3}$, Patrice Bourgault ${ }^{4}$, Geneviève Dubois ${ }^{3}$, \\ Pierre CANAC-MARQuis ${ }^{5}$, and François-JosePh LAPOINTE ${ }^{3}$
}

${ }^{1}$ Département de Conservation et Recherche, Zoo de Granby, 525 rue St-Hubert, Granby, Quebec J2G 5P3 Canada

${ }^{2}$ Direction de la gestion de la faune de l'Estrie, de Montréal et de la Montérégie et de Laval, Ministère des Forêts, de la Faune et des Parcs, 201 Place Charles-Le Moyne, Longueuil, Quebec J4K 2T5 Canada

${ }^{3}$ Département de sciences biologiques, Université de Montréal, C.P. 6128, Succursale Centre-Ville, Montréal, Quebec H3C 3J7 Canada

${ }^{4}$ Département de biologie, Faculté des Sciences, Université de Sherbrooke, 2500 boulevard de 1’Université, Sherbrooke, Quebec J1K 2R1 Canada

${ }^{5}$ Direction de la faune terrestre, Ministère des Forêts, de la Faune et des Parcs, 880 Chemin Ste-Foy, Québec, Quebec G1S 4X4 Canada

${ }^{6}$ Corresponding author: 1lazure@zoodegranby.com

Lazure, Louis, Patrick Paré, Nathalie Tessier, Patrice Bourgault, Geneviève Dubois, Pierre Canac-Marquis, and François-Joseph Lapointe. 2016. Known range expansion and morphological variation in the Southern Flying Squirrel (Glaucomys volans) in Quebec. Canadian Field-Naturalist 130(3): 216-221.

New records of the Southern Flying Squirrel (Glaucomys volans) in Quebec expand its known range in the province $150 \mathrm{~km}$ east to the Appalachian foothills and farther west than previously assumed. We obtained individuals through live trapping, trapper collaboration, and opportunistic discoveries. Species identification was confirmed with morphological traits and molecular analysis. Individuals were smaller in the eastern part of the province in terms of mass, total length, and tail length. Some live captures also seem to corroborate the fact that Southern Flying Squirrels are mainly associated with mature hardwood forests.

Key Words: Southern Flying Squirrel; Glaucomys volans; range expansion; habitat; morphology

De nouvelles mentions du petit polatouche (Glaucomys volans) au Québec permettent d'étendre son aire de répartition connue jusqu'à $150 \mathrm{~km}$ à l'est dans les contreforts des Appalaches et plus à l'ouest que présumé. Les spécimens ont été obtenus via des captures vivantes, la collaboration des trappeurs et des découvertes opportunistes. L'identification de l'espèce a été confirmée sur des bases morphologiques et moléculaires. Les individus étaient plus petits dans l'est de la province en considérant la masse, la longueur totale et celle de la queue. Les quelques captures d'animaux vivants semblent corroborer que le petit polatouche est davantage associé, au niveau de l'habitat, aux peuplements de feuillus matures.

Mots clés : Petit polatouche; Glaucomys volans; expansion; habitat; morphologie; répartition

\section{Introduction}

The genus Glaucomys, which belongs to the flying squirrel tribe (Pteromyini, family Sciuridae), is found in North America, including Mexico and some parts of Central America (Arbogast 2007). The two species of this genus are the Southern Flying Squirrel (G. volans) and the Northern Flying Squirrel (G. sabrinus). The latter is widespread in Canada, with its range extending to the northern tree line (Wells-Gosling and Heaney 1984). In contrast, a review of the status of the Southern Flying Squirrel (COSEWIC 2006) identified two distinct populations in Canada: the Great Lakes Plains population in Ontario and Quebec and the Atlantic (Nova Scotia) population. Although the status of both was assessed as "not at risk" (COSEWIC 2006), in Quebec, G. volans is classified as "susceptible to being designated threatened or vulnerable" under the provincial act on threatened or vulnerable species (MFFP 2001). The known range of G. volans in Quebec is limited to small parts of the Outaouais, Laurentides, and
Montérégie regions (Dolan and Carter 1977; MFFP 2001; COSEWIC 2006). South of the Canada-United States border, G. volans is present in the New England states (Cameron 1976; Weigl 1978; Fridell and Litvaitis 1991; Stapp and Mautz 1991); however, according to J. Litvaitis, its presence in the north of these states, closer to Quebec, is uncertain (COSEWIC 2006: 9). Nevertheless, members of the Committee on the Status of Endangered Wildlife in Canada believed it was "likely present" in the Estrie region, as far east as Sherbrooke and Mont-Mégantic (COSEWIC 2006).

A few studies describe $G$. volans habitat in temperate zones outside of Quebec. The species is associated with old-growth deciduous or mixed forests, containing mast-producing trees (Weigl 1978; Taulman 1999; Lavers 2004). Younger forests ( $<40$ years) and pine plantations are avoided (Taulman 1999; Taulman and Smith 2004), but Holloway and Malcolm (2007) found higher G. volans densities in logged sites (which presumably have more abundant mast) than in old forest in Algonquin Park, Ontario.

A contribution towards the cost of this publication has been provided by the Thomas Manning Memorial Fund of the Ottawa Field-Naturalist's Club. 
The main objective of our study was to update the range of G. volans in Quebec. Given the little effort devoted to the study of this species in the past, it is essential to report a more accurate distribution and possible connections with nearby populations and, eventually, clarify the species' status. We also wanted to verify, within the context of our study, the assumption that $G$. volans is associated with mature deciduous forests. Taking advantage of the specimens at hand, we documented phenotypic variation in $G$. volans based on four morphological traits, because morphological data from Quebec specimens of $G$. volans have yet to be collated and published. Species identification was further confirmed by genetic analyses.

\section{Methods}

\section{Live captures}

Trapping periods were from 30 October to 18 November 2013 and from 18 August to 8 October 2014. Four sites were explored, one in eastern Montérégie and three in Estrie: Parc national de la Yamaska $\left(45^{\circ} 26^{\prime} \mathrm{N}, 72^{\circ} 34^{\prime} \mathrm{W}\right)$, Sherbrooke $\left(45^{\circ} 25^{\prime} \mathrm{N}, 71^{\circ} 54^{\prime} \mathrm{W}\right)$, Kingsbury $\left(45^{\circ} 35^{\prime} \mathrm{N}, 72^{\circ} 09^{\prime} \mathrm{W}\right)$, and Johnville Bog and Forest Park $\left(45^{\circ} 21^{\prime} \mathrm{N}, 71^{\circ} 45^{\prime} \mathrm{W}\right)$. We developed and followed a standard protocol available from the Ministère des Forêts, de la Faune et des Parcs du Québec (MFFP; Tessier et al. 2015). The goal was not to estimate density from captures; thus, we targeted groups of trees or single trees that offered potential for capture based on criteria described in the literature (i.e., large or decaying trees, dense and connected canopy), but we also explored various types of stands with different species composition and age structure.

Tomahawk traps, models 102, 103 and 202 (Tomahawk Live Trap, Hazelhurst, Wisconsin, USA) were placed at stations about $30 \mathrm{~m}$ apart. Horizontal wooden platforms were installed 1.5-2 $\mathrm{m}$ above ground on trees with a diameter at breast height of at least $38 \mathrm{~cm}$ and attached to the trunk using 122-cm tie-wraps. Traps were placed on the platforms and covered with a corrugated plastic shell, leaving the main opening free. These covers protect the trapped animal from bad weather and limit escape attempts that may cause injuries. Traps and covers were fixed in place using bungee cords. A handful of cotton wool was put in the back of each trap as insulation for the animals; it was changed after each capture. Bait consisted of a piece of apple with a halfteaspoon of peanut butter. Traps were pre-baited a week in advance to allow animals to become familiar with them before trapping began (Rodas et al. 2009).

During trapping periods, traps were visited every day. We opened them within $2 \mathrm{~h}$ before sunset and verified and closed them within $2 \mathrm{~h}$ after sunrise; thus, traps were inactive during the day. Two people were needed to facilitate handling. After transferring an animal to a fabric bag, we obtained a tissue sample, marked the squirrel with an ear tag or, temporarily, by cutting hair on the back, weighed it with a $100-\mathrm{g}$ or $300-\mathrm{g}$ Pesola balance (Pesola, Schindellegi, Switzerland), and identified it from ventral hair. Tissue samples were taken from the ear with a sterilized 3-mm punch and immediately put into $95 \%$ alcohol.

Between 17 and 40 traps were set simultaneously at a given site. Sampling effort totalled 1540 trap nights. We trapped from seven to 10 days at each site. One site, Johnville Bog and Forest Park, was visited both years, and many locations were explored within the park. The Kingsbury site had been sampled in 2012 (Bourgouin et al. 2012) with a similar method.

Trapping and handling were in accordance with a scientific permit and an animal care certificate provided by MFFP for each trapping season.

\section{Trappers' accidental catches}

In 2010, the MFFP solicited participation by trappers throughout the province, and this collaboration has been renewed in each subsequent trapping season. Trappers participated by sending us the carcasses of flying squirrels accidentally caught in their traps. These quick killing traps were set primarily to capture American Martens (Martes americana) during the commercial fur trapping season, mainly in November and December.

\section{Morphological identification}

Morphological identification was based on three criteria. First, the hairs on the belly of $G$. volans are completely white, from base to tip (Dolan and Carter 1977), whereas the ventral hairs of G. sabrinus are grey at the base and white at the tip (Wells-Gosling and Heaney 1984; Dolan and Carter 1977). Second, the species differ in mass: G. volans, 46-85 g; G. sabrinus, 95-110 g (Dolan and Carter 1977; Jeff Bowman, personal communication). Third, total length is $198-255 \mathrm{~mm}$ for $G$. volans and more than $260 \mathrm{~mm}$ for G. sabrinus (Dolan and Carter 1977; Hall 1981). Therefore, to identify specimens and document phenotypic variation, four morphological traits were measured: total length (nose to end of tail), tail length, hind foot length, and mass. Lengths were measured with a simple ruler and weight was obtained with an electronic balance (Scout Pro, SP401, Ohaus Corp., Parsippany, New Jersey, USA). Each trait was separately compared between sexes and regions using non-parametric Kruskal-Wallis tests.

\section{Genetic identification}

The two species of flying squirrels can also be distinguished based on molecular criteria (Arbogast et al. 2005; Rogic et al. in press). With the simple morphological identification process, there is a risk of confusion between $G$. volans and juvenile $G$. sabrinus. Some carcasses were also in bad condition and were harder to identify. In addition, there is no unequivocal way to identify hybrids (Garroway et al. 2010). In such cases, genetic analyses with species-specific primers can confirm the species identity.

DNA was extracted from tissue samples using quick lysis (Olsen et al. 1996). For each sample, we amplified three specific primers: two for the cytochrome B 
(Cytb) mitochondrial gene and one for the cannabinoid receptor type 1 (CNR1) nuclear gene. Polymerase chain reaction (PCR) was done in $10 \mu \mathrm{L}$ containing 100-250 ng of DNA extract, $1 \times$ reaction buffer, $2.5 \mathrm{mmol} / \mathrm{L} \mathrm{MgCl}_{2}, 0.25 \mathrm{mmol} / \mathrm{L}$ of each dNTP, $0.6 \mu \mathrm{mol} / \mathrm{L}$ of each primer, $0.5 \mathrm{U}(1 \mathrm{U} \approx 16.67$ nkat $)$ Taq polymerase, and $6.74 \mu \mathrm{L}$ sterile water. Amplification was done using a GeneAmp PCR System 9700 thermal cycler (Applied Biosystems now part of Thermo Fischer Scientific, Waltham, Massachusetts, USA) programmed with an initial denaturation at $94^{\circ} \mathrm{C}$ over $120 \mathrm{~s}$, followed by 12 cycles of $30 \mathrm{~s}$ at $94^{\circ} \mathrm{C}, 30 \mathrm{~s}$ at $55^{\circ} \mathrm{C}$ (reduction of $1^{\circ} \mathrm{C} /$ cycle), and $40 \mathrm{~s}$ at $72^{\circ} \mathrm{C}$. The second step consisted of 25 cycles of $30 \mathrm{~s}$ at $94^{\circ} \mathrm{C}, 30 \mathrm{~s}$ at $50^{\circ} \mathrm{C}$, and $40 \mathrm{~s}$ at $72^{\circ} \mathrm{C}$. Final extension lasted $600 \mathrm{~s}$ at $72^{\circ} \mathrm{C}$. A mix of bromophenol blue and SYBR Green I nucleic acid gel stain (Invitrogen Inc., Burlington, Ontario, Canada) was added to the PCR product and migrated on 2\% agarose gels. Amplification success was visualized with an ultraviolet lamp. These techniques can identify first-generation hybrids. In this case, hybrids can be genotyped using microsatellites SF-15 where two discriminant alleles could be observed. These methods are described in Rogic et al. (in press).

\section{Results}

Glaucomys volans was found in Estrie $(n=13)$, Montérégie $(n=9)$, and Outaouais regions $(n=73)$; the city of Sherbrooke is now the easternmost location reported for this species in Quebec (Figure 1). The western limit of the species has also expanded from the previous known range based on confirmation of $G$. volans being trapped at many locations in the LacNilgaut area.

All live captures $(n=10)$ occurred in Estrie (nine in Kingsbury and one in Sherbrooke). The relative abundance of $G$. volans and $G$. sabrinus in live captures is shown in Table 1. No live captures occurred in Parc national de la Yamaska and only G. sabrinus was trapped in Johnville.

The distribution of $G$. volans and $G$. sabrinus differed in relation to stand type (Fisher's exact test, $P<0.001)$. Although $G$. sabrinus was captured alive in various stand types (uneven-aged deciduous $n=2$, uneven-aged mixed $n=12$, even-aged coniferous $n=$ 4 ), all our $G$. volans live captures occurred in unevenaged deciduous forest stands.

In all, 759 dead flying squirrels were submitted, the vast majority coming from trappers' accidental catches with a few opportunistic finds of citizens. Of the catch-

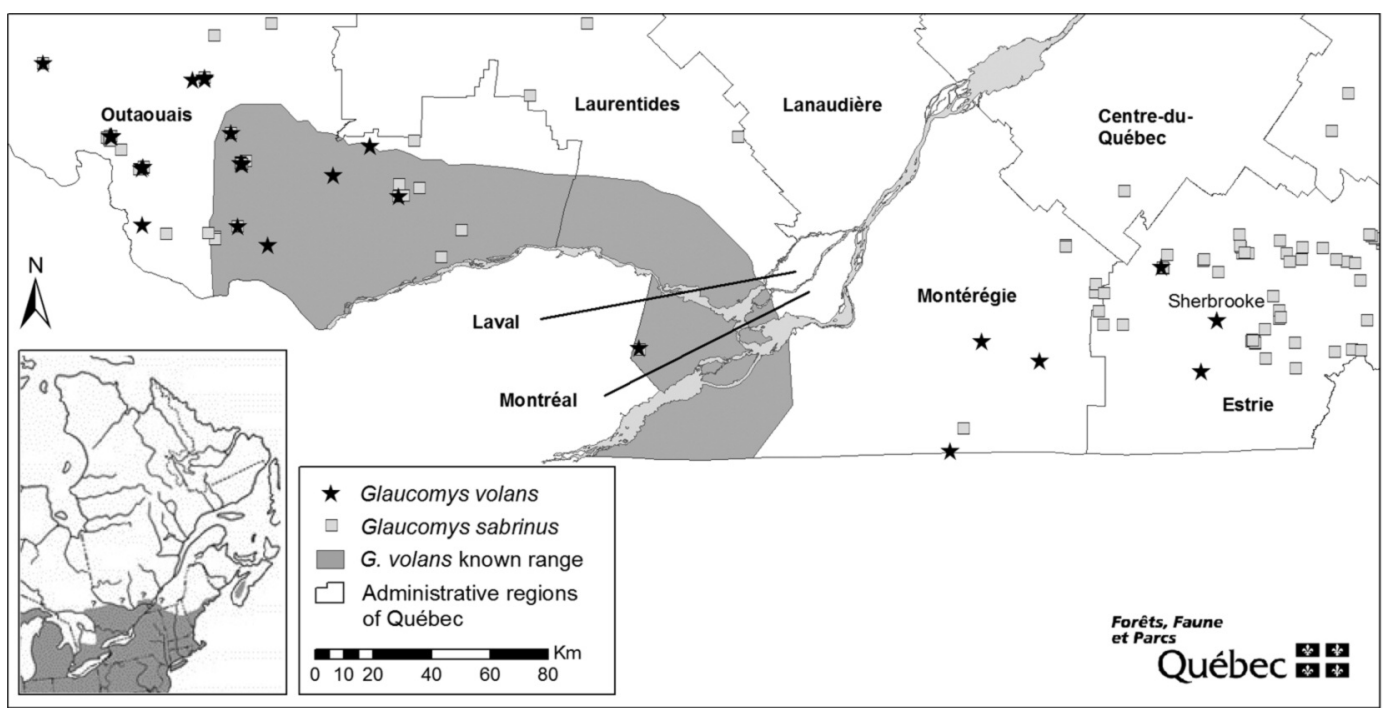

FIGURE 1. Current known range of the Southern Flying Squirrel (Glaucomys volans) in Quebec and locations of Southern (black stars) and Northern (G. sabrinus; grey squares) Flying Squirrels captured from 2009 to 2015. Inset map shows distribution of the Southern Flying Squirrel in the northeast part of its range (COSEWIC 2006).

TABLE 1. Relative abundance of Southern (Glaucomys volans) and Northern (G. sabrinus) Flying Squirrels at four sites in southern Quebec based on live-trapping effort (2013-2014).

\begin{tabular}{lccc}
\hline \hline Location & Trap nights & G. volans per 100 trap nights & G. sabrinus per 100 trap nights \\
\hline Parc nationale de la Yamaska & 210 & 0.00 & 0.00 \\
Sherbrooke & 169 & 0.59 & 0.00 \\
Kingsbury & 398 & 2.26 & 0.25 \\
Johnville Bog and Forest Park & 763 & 0.00 & 1.57 \\
\hline \hline
\end{tabular}


es, $11 \%(n=85)$ were confirmed to be $G$. volans (see Table 2 for a breakdown by region). Measurement of 71 squirrels produced the following means $( \pm$ standard deviation): mass $65 \pm 11 \mathrm{~g}$, total length $231 \pm 14 \mathrm{~mm}$, tail length $100 \pm 7 \mathrm{~mm}$, and hind foot $31 \pm 2 \mathrm{~mm}$. It was not possible to measure all four variables on all individuals. No significant differences were detected between males and females for the four variables tested (mass $\chi^{2}=3.78, P=0.052$; total length $\chi^{2}=2.07$, $P=0.150$; tail length $\chi^{2}=0.39, P=0.531$; and hind foot $\left.\chi^{2}=0.40, P=0.525\right)$. On the other hand, regional differences were detected for total length $\left(\chi^{2}=6.39\right.$, $P=0.041)$, tail length $\left(\chi^{2}=9.07, P=0.011\right)$, and mass $\left(\chi^{2}=9.94, P=0.007\right)$. Comparing mean values between regions revealed that $G$. volans from Outaouais were $24 \%$ heavier $(67 \pm 10 \mathrm{~g}$ versus $54 \pm 11 \mathrm{~g}), 19 \%$ longer $(233 \pm 12 \mathrm{~mm}$ versus $195 \pm 7 \mathrm{~mm})$, and had $12 \%$ longer tails (101 $\pm 7 \mathrm{~mm}$ versus $90 \pm 12 \mathrm{~mm}$ ) than those from Estrie. In contrast, hind foot length was constant throughout the regions $\left(\chi^{2}=1.59, P=0.450\right)$. Morphological identification was effective and reliable for the most part and showed concordance with genetic identification 297 times out of 301 .

TABLE 2. Number of dead Southern (Glaucomys volans) and Northern (G. sabrinus) Flying Squirrels submitted from 10 administrative regions of Quebec (2010-2014).

\begin{tabular}{lcc}
\hline \hline Region & G. volans $(\%)$ & G. sabrinus \\
\hline Abitibi-Témiscamingue & $0(0.0)$ & 31 \\
Bas-Saint-Laurent & $0(0.0)$ & 10 \\
Capitale-Nationale & $0(0.0)$ & 12 \\
Chaudière-Appalaches & $0(0.0)$ & 7 \\
Côte-Nord & $0(0.0)$ & 16 \\
Estrie & $3(1.7)$ & 177 \\
Laurentides & $0(0.0)$ & 103 \\
Mauricie & $0(0.0)$ & 1 \\
Montérégie & $9(45.0)$ & 20 \\
Outaouais & $73(24.6)$ & 297 \\
\hline \hline
\end{tabular}

Genetic identification was performed on a subset of 369 squirrels. After Cytb multiplex amplification, the presence of a single band at $408 \mathrm{bp}$ indicated that the sample was that of $G$. volans. The presence of two bands, a standard one at 408 bp and a small specific band at approximately $104 \mathrm{bp}$, revealed the sample to be that of $G$. sabrinus. For the CNR1 multiplex amplification, the presence of a band at $208 \mathrm{bp}$ designates an individual as $G$. sabrinus; $G$. volans amplifies the standard band at 466 bp but lacks the 208 bp band. Of the 369 samples, 54 were identified as G. volans and 315 as G. sabrinus. Three of these specimens were morphologically misidentified as $G$. volans when they were in fact $G$. sabrinus. Furthermore, our genetic methods helped resolve the identification of 16 carcasses, whose morphological measurements were incomplete and, thus, unidentifiable without genetic methods. The results obtained for both mitochondrial and nuclear DNA for each individual were congruent, suggesting that no F1 hybridization was apparent within our dataset.

\section{Discussion}

The new range of $G$. volans in Quebec extends to Sherbrooke and North Hatley, $150 \mathrm{~km}$ east of the previous known range and farther into the range of $G$. sabrinus. There is also evidence that the range has expanded by at least $60 \mathrm{~km}$ west of the current limit in the Outaouais region. Since the first discovery of $G$. volans in Quebec (Youngman and Gill 1968), near Gatineau, Outaouais, it has been unclear whether its range expansion is real or simply an artifact of limited sampling efforts. Although limited sampling might explain some of our discoveries, expansion of G. volans' range has been documented in Ontario and Michigan (Bowman et al. 2005; Myers et al. 2009), and expansion could also be occurring in Quebec. However, as stated by Bowman et al. (2005), the northern edge of $G$. volans' range is dynamic and could contract if harsh conditions, such as cold temperatures and reduced mast crop, affect the region and slow the long-term expansion of the species.

This update on the range of $G$. volans in southern Quebec shines a new light on potential links with populations in neighbouring provinces and states. It seems plausible that a more or less continuous distribution from Outaouais to Estrie contributes to maintain a stronger connection between the Great Lake Plains population and the one in the Appalachian forests of New England. The possibility that there is a link with the Atlantic population remains weak despite this expansion, as that population is isolated by the geographic bottleneck effect of the Chignecto isthmus, and $G$. volans is considered absent from this area, despite reported search efforts (COSEWIC 2006; Lavers et al. 2006).

At the habitat level, our results are in line with previous studies that showed that $G$. volans is mostly dependent on deciduous forests with mast-producing trees (Weigl 1978; Taulman 1999; Lavers 2004; Taulman and Smith 2004) and that G. sabrinus is more of a generalist (Weigl 1978, 2007; Trudeau et al. 2011). However, our sampling method was biased toward what we deemed to be good habitat for flying squirrels, and our limited sample size is not enough to confirm a species-related preference in our study area. This information would be useful for the management of deciduous forests because $G$. volans could be used as an indicator species in studying the impact of timber harvest in the southern part of the province. The use of flagship species is one of the tools used by the MFFP to achieve their goal of sustainable management of natural resources.

Morphologically, all measurements of $G$. volans caught in Quebec fall within the range reported in Dolan and Carter (1977), who also mention that sexual dimorphism is not conspicuous in this species. Three 
out of four measurements were significantly smaller in the eastern region of Estrie compared to the more western specimens. This trend makes sense when viewed in a larger context. Namely, comparing our results with those reported by Lavers (2004) revealed that $G$. volans in Quebec have longer tails $(100 \pm 7 \mathrm{~mm})$ than those in Nova Scotia $(81.1 \pm 5.5 \mathrm{~mm})$, but tail length is similar to those in Ontario $(101 \pm 9.1 \mathrm{~mm})$. Specimens from Nova Scotia also weigh less $(58 \pm 7 \mathrm{~g})$ than those from Quebec (64 $\pm 9 \mathrm{~g})$, but are closer to the mean weight of our eastern specimens $(54 \pm 11 \mathrm{~g})$. Data for G. sabrinus from the same regions present a similar longitudinal trend only in terms of tail length $\left(\chi^{2}=7.92, P=0.019\right)$. Tails of Outaouais specimens are approximately $3.7 \%$ (or $4 \mathrm{~mm}$ ) longer than those of specimens from the other two regions (unpublished data).

In conclusion, we believe that the range of $G$. volans should be updated based on the results of our study. This information will also be useful when re-evaluating the species' status. Investigating $G$. volans abundance and population dynamics, not just presence or absence, is a further step to be taken toward a better understanding of the species' ecology. Its discovery in the same regions as $G$. sabrinus also opens up new possibilities for research on its ecological role, habitat use, and further range expansion in light of climate change.

\section{Acknowledgements}

We thank Fanie Pelletier and Jacinthe Gosselin from the Universite de Sherbooke for logistical support and field assistance essential to the project; Maya Petit, François Petit, and Lorraine Bourget for allowing access to their property, providing field assistance, and their interest in getting to know their surrounding wildlife; Lucie Veilleux (map), René Houle, Olivier Cameron Trudel, Stéphanie Cholette, and Florent Lemieux of the Ministère des Forêts, de la Faune et des Parcs for their involvement at various levels; trappers who contributed flying squirrel specimens; Jeff Bowman, Research Scientist at Ontario Ministry of Natural Resources and Forestry, and Adjunct Professor at Trent University, for providing useful information at an early stage of our study; Alain Mochon for permission to work in Parc national de la Yamaska and for field assistance; Julie Hébert (Zoo de Granby) and Mathieu Paradis (Université Laval) for assisting in morphological measurements.

\section{Literature Cited}

Arbogast, B. S. 2007. A brief history of the New World flying squirrels: phylogeny, biogeography, and conservation genetics. Journal of Mammalogy 88: 840-849.

Arbogast, B. S., R. A. Browne, P. D. Weigl, and G. J. Kenagy. 2005. Conservation genetics of endangered flying squirrels (Glaucomys) from the Appalachian mountains of eastern North America. Animal Conservation 8: 123-133.

Bourgouin, M., J.-P. Lalumière, and M. Petit. 2012. Détermination de l'habitat préférentiel du petit polatouche et du grand polatouche. Cégep de Sherbrooke, Sherbrooke, Quebec, Canada.

Bowman, J., G. L. Holloway, J. R. Malcolm, K. R. Middel, and P. J. Wilson. 2005. Northern range boundary dynamics of southern flying squirrels: evidence of an energetic bottleneck. Canadian Journal of Zoology 83: 1486-1494.

Cameron Jr., D. M. 1976. Distribution of the Southern Flying Squirrel (Glaucomys volans) in Maine. Canadian FieldNaturalist 90: 173-174.

COSEWIC (Committee on the Status of Endangered Wildlife in Canada). 2006. Assessment and update status report on the southern flying squirrel Glaucomys volans Atlantic (Nova Scotia) population and Great Lakes Plains population in Canada. COSEWIC, Ottawa, Ontario, Canada. Accessed 18 May 2016. http://www.registrelep-sararegistry .gc.ca/virtual_sara/files/cosewic/sr_southern_flying_squir rel_e.pdf

Dolan, P. G., and D. C. Carter. 1977. Glaucomys volans. Mammalian Species 78: 1-6.

Fridell, R. A., and J. A. Litvaitis. 1991. Influence of resource distribution and abundance on home-range characteristics of southern flying squirrels. Canadian Journal of Zoology 69: 2589-2593.

Garroway, C. J., J. Bowman, T. J. Cascaden, G. L. Holloway, C. G. Mahan, J. R. Malcolm, M. A. Steele, G. Turner, and P. J. Wilson. 2010. Climate change induced hybridization in flying squirrels. Global Change Biology 16: $113-121$.

Hall, E. R. 1981. The Mammals of North America, Volume 1. Second edition. John Wiley and Sons, New York, New York, USA.

Holloway, G. L., and J. R. Malcolm. 2007. Nest-tree use by Northern and Southern Flying Squirrels in central Ontario. Journal of Mammalogy 88: 226-233.

Lavers, A. J. 2004. Spatial ecology in a northern disjunct population of southern flying squirrel, Glaucomys volans. M.Sc. thesis, Acadia University, Wolfville, Nova Scotia, Canada.

Lavers, A. J., S. D. Petersen, D. T. Stewart, and T. B. Herman. 2006. Delineating the range of a disjunct population of Southern Flying Squirrels (Glaucomys volans). American Midland Naturalist 155: 188-196.

MFFP (Ministère des Forêts, de la Faune et des Parcs). 2001. Liste des espèces fauniques menacées ou vulnérables au Québec : Petit polatouche. Accessed 23 September 2016. http://www3.mffp.gouv.qc.ca/faune/especes/menacees/fi che.asp? noEsp $=63$

Myers, P., B. L. Lundrigan, S. M. G. Hoffman, A. P. Haraminac, and S. H. Seto. 2009. Climate-induced changes in the small mammal communities of the Northern Great Lakes Region. Global Change Biology 15: 1434-1454.

Olsen, J. B., J. K. Wenburg, and P. Bentzen. 1996. Semiautomated multilocus genotyping of Pacific Salmon (Oncorhynchus spp.) using microsatellites. Molecular Marine Biology and Biotechnology 5: 259-272.

Rodas, L. R., C. A. Jennison, D. B. Hall, and G. W. Barrett. 2009. Luring small mammals: a levels-of-organization perspective. Southeastern Naturalist 8: 387-398.

Rogic, A., G. Dubois, N. Tessier, P. Paré, P. Canac-Marquis, and F.-J. Lapointe. In press. Applying genetic methods to identify northern and southern flying squirrels and determine conservation needs. Conservation Genetics Resources.

Stapp, P., and W. W. Mautz. 1991. Breeding habits and postnatal growth of the Southern Flying Squirrel (Glaucomys 
volans) in New Hampshire. American Midland Naturalist 126: 203-208.

Taulman, J. F. 1999. Selection of nest trees by southern flying squirrels (Sciuridae: Glaucomys volans) in Arkansas. Journal of Zoology 248: 369-377.

Taulman, J. F., and K. G. Smith. 2004. Home range and habitat selection of southern flying squirrels in fragmented forests. Mammalian Biology 68: 1-17.

Tessier, N., G. Dubois, P. Paré, and S. Pelletier. 2015. Protocole d'inventaire des petits et grands polatouches du Québec. Secteur de la Faune, Ministère des Forêts, de la faune et des parcs, Québec, Quebec, Canada.

Trudeau, C., L. Imbeau, P. Drapeau, and M. J. Mazerolle. 2011. Site occupancy and cavity use by the Northern Flying Squirrel in the boreal forest. Journal of Wildlife Management 75: 1646-1656.
Wells-Gosling, N., and L. R. Heaney. 1984. Glaucomys sabrinus. Mammalian Species 229: 1-8.

Weigl, P. D. 1978. Resource overlap, interspecific interactions and the distribution of the flying squirrels, Glaucomys volans and G. sabrinus. American Midland Naturalist 100: 83-96.

Weigl, P. D. 2007. The northern flying squirrel (Glaucomys sabrinus): a conservation challenge. Journal of Mammalogy 88: 897-907.

Youngman, P. M., and D. A. Gill. 1968. First record of the Southern Flying Squirrel, Glaucomys volans volans, from Quebec. Canadian Field-Naturalist 82: 227-228.

Received 9 November 2015

Accepted 30 May 2016 